\title{
Manson's schistosomiasis in the undernourished mouse: some recent findings
}

\author{
Eridan M Coutinho/ ${ }^{+}$, Sheilla A de Oliveira, Andréia F de Barros, Fabiana L Silva, Renata P Ramos \\ Laboratório de Imunopatologia e Biologia Molecular, Centro de Pesquisas Aggeu Magalhães-Fiocruz, CP 7472, 50670-420 Recife, PE, Brasil
}

This paper deals with current knowledge of the interrelationships between Schistosoma infection and malnutrition. It emphasizes the relevance of these investigations in the face of dynamic and evolving changes occurring in population diets and changes in the epidemiological patterns of schistosomiasis in endemic countries. The paper further discusses the basis for continuing the studies on this subject and the reasons why it represents a misunderstood association. This review also focuses on the cellular and humoral immune responses in the undernourished mouse model infected with Schistosoma mansoni, with updated information on the immune response in wild-type and iNOS knockout mice concerning soluble egg antigen specific antibodies and kinetics of IFN- $\gamma, I L-4, I L-10$ and IL-13 cytokines, in the chronic phase of Manson's schistosomiasis. There is indication that schistosome-infected undernourished mice are able to develop a humoral immune response, but antibody titres are much lower than in the control animals. Cytokine production (IFN- $\gamma, I L-4, I L-10)$ is lower in the undernourished mice, but as infection progresses to the chronic phase its kinetics run an antagonistic course when compared to that of well-nourished animals. Marked variation in the secretion of IL-13 (a fibrogenic cytokine) could explain why undernourished mice do not develop liver "pipe-stem" fibrosis described in previous papers on well-nourished animals.

Key words: Schistosoma mansoni - undernutrition - immunopathology

Based on the literature on the interaction between malnutrition and schistosome-infection, it can be concluded that it is still necessary to get a deeper insight into the subject, considering incomplete information and sometimes conflicting results reported in some publications.

The purpose of this paper is to stress the relevance of studying the paradigm of the interaction of malnutrition (particularly undernutrition) and schistosome-infection, in the face of dynamic and evolving changes in population diets and schistosomiasis epidemiology patterns currently described. This review also intends to validate the use of the outbred and inbred mouse models for investigations on the schistosomiasis/malnutrition association, reporting on recent findings from our laboratory and others about immune response and liver pathology in undernourished mice infected with Schistosoma mansoni.

\section{Why study malnutrition in association with schistosome infection?}

There are several reasons for continuing studies on this association: (i) the frequent overlapping of endemic zones for Schistosoma infection and undernutrition in Brazil and other emerging countries of the developing world, where at least $16 \%$ of the total population living in Africa, Asia and Latin America are under the risk of hunger (WFP 2006), (ii) the important role of nutrition in health, in low-income and middle-income countries, es-

+Corresponding author: eridan@cpqam.fiocruz.br

Received 9 January 2009

Accepted 13 November 2009 timating that around $32 \%$ of the overall disease burden, in terms of mortality and morbidity, would be removed by eliminating malnutrition (Mason et al. 2003), (iii) the concept of parasite-host-environment as interrelated subsystems, the host nutritional status being included in this context, (iv) the growing importance of the paradigm of the interaction of malnutrition and infection (Solomons 2007), (v) the urbanisation and appearance of new epidemiological profiles of schistosomiasis, emphasising the role of biological, social, economic, political and cultural determinants in the natural history of this helminthiasis, reflecting on the host nutritional status, (vi) the recognition of nutrition as a critical determinant of the immune response, epidemiological and clinical studies stressing that nutritional deficiencies alter immunocompetence (Chandra 1992), which further increase the risk and influence the outcome of infection (Meira 1995, Scrimshaw \& SanGiovanni 1997, Fraker et al. 2000, CunninghamRundles et al. 2005, Landgraf et al. 2007, Solomons 2007) and, finally, (vii) the need for a deeper evaluation on the real importance of nutrition in schistosome-infected hosts, in view of incomplete and sometimes contradictory results reported in the literature.

\section{Schistosomiasis and malnutrition: why is this as- sociation still misunderstood?}

There are several reasons to explain why the interrelationships between schistosomiasis and malnutrition still represent a misunderstood association. In humans: (i) the use of non-standardised and even inadequate methodologies in field investigations, with most papers describing cross-studies or inadequate sample sizes, (ii) the results are randomly chosen, focusing on either the acute or the chronic phase of the disease, (iii) work is done in areas of low prevalence for malnutrition or low 
intensity of infection and morbidity for schistosomiasis and (iv) generalised conclusions are based only on the clinical form of schistosomiasis locally prevalent, which may influence the type and severity of associated malnutrition. In animal models: (i) the use of diverse experimental animal models, such as mice, rats, gerbils and hamsters, (ii) results are based upon infections with different Schistosoma species and parasite strains, (iii) different methodological approaches are used to induce undernutrition, including mice age at the beginning of the experiment and the use of different experimental diets and (iv) difficulties in applying the results obtained with animal models to humans.

\section{Animal models used in experiments on the association schistosomiasis/malnutrition}

The need for the use of experimental animals and their contribution to elucidate several aspects of human diseases has been recognized a long time ago. Warren (1968) stated: "the elucidation of the pathophysiology and pathogenesis of a disease has rarely been achieved by study of the human patient alone, requiring almost invariably the development of an animal model".

Besides being used to reproduce anatomo-pathologic and pathophysiologic features of the infection in humans, laboratory animals have also been frequently utilised for the study of immunity and treatment.

In the particular case of studies on the schistosomiasis/malnutrition association, outbred and inbred mice of different lineages have been widely used (Dewitt 1957, Kanuft \& Warren 1969, Akpom \& Warren 1975, Coutinho et al. 1991, 1992, 1997, 2003, 2007), but other experimental hosts, such as the albino rat (Bhattacharyya 1965, Parent et al. 1984), the gerbil (Hashem \& Fahmy 1962) and the hamster (Mansour et al. 1983) have also been mentioned in investigations on the above association.

\section{Liver pathology and schistosomiasis: the importance of the hepatic fibrosis}

Liver fibrosis is the most important tissue lesion found in schistosome-infected hosts. The chronic granulomatous host response around disseminated parasite eggs, aggravated by fibrosis, is the major contributor to the pathology of the disease (Colley 1981, Smithers \& Doenhoff 1982, Warren 1982). T helper (Th) cells $\left(\mathrm{CD}_{4}^{+}\right.$ $\mathrm{T}$ cells) are instrumental for the formation of granulomas around S. mansoni eggs (Mathew \& Boros 1986). Moreover, $\mathrm{CD}_{8}^{+} \mathrm{T}$ cells appear to be important for downregulation of granuloma size in chronic infections (Henderson et al. 1992), but antibodies are necessary in addition to down-regulated T cells (Jankovic et al. 1998).

Fibrosis enhances the disease pathology, as it is an important feature of advanced schistosomiasis, both in man and in experimental animal models. It represents the anatomical counterpart of the clinical condition known as hepato-splenic schistosomiasis. It follows the granulomatous inflammatory response and occurs mostly at the site of the resolving granulomatous reactions, but fibrosis bands also appear around portal veins distant from granulomas, being partly a sequel to the chronic thrombophlebitis of portal veins. In addition to portal fibrosis, collagen bundles are found in Disse's spaces

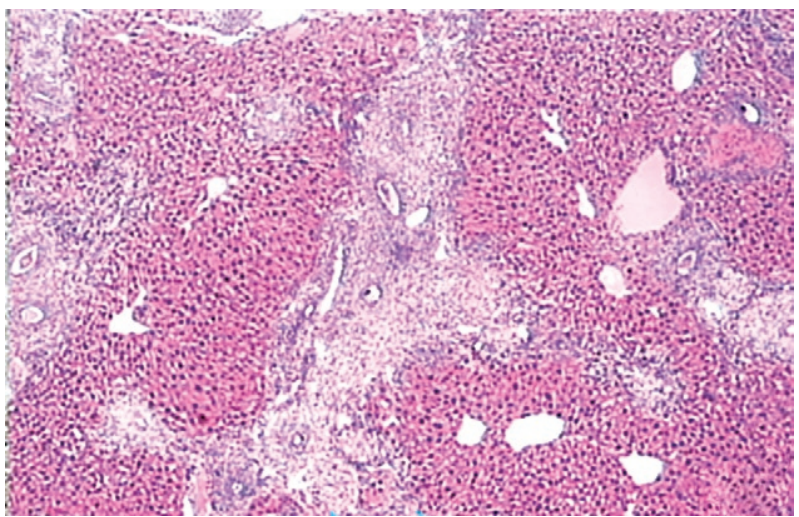

Fig. 1: murine periportal liver fibrosis in a well-nourished outbred Swiss mouse with 16 days of infection with Schistosoma mansoni. H\&E 100X.

located underneath the liver sinusoids between the endothelium and the hepatocytes (Boros 1989).

Although the pathogenesis of human pipe-stem fibrosis is still not well understood, the host immune response appears to be involved in the overall process of fibrosis (Boros 1989).

Thirty to $50 \%$ of well-nourished outbred albino Swiss mice subjected to relatively mild (1-2 worm pairs) and prolonged infections (16 weeks or more) with $S$. manso$n i$, develop a lesion similar to human Symmer's fibrosis (Fig. 1), as a consequence of a massive and continuous deposition of eggs along the dilated intra-hepatic venous portal branches (Andrade 1987, Andrade \& Cheever 1993, Andrade et al. 1997).

However, previous study in our laboratory showed that undernourished mice maintained under the same conditions completely failed to develop the "pipe-stem" fibrosis of the liver, unlike the well-nourished controls (Coutinho et al. 1997).

Various attempts to induce the pipe-stem like liver fibrosis in undernourished mice have been unsuccessful, such as: shifting from a deficient to a balanced diet and vice-versa (Coutinho et al. 2003); repeated infections five times at 15day intervals (Coutinho et al. 2007) and assays with BALB/c and C57BL/10 inbred mouse strains (Coutinho 2004).

\section{Immune response in well-nourished mice infected with $S$. mansoni}

The pathogenesis of schistosomiasis in well-nourished mice is known to be dependent on immunologic phenomena, such as the formation of delayed hypersensitivitytype granuloma around parasite eggs trapped in the liver (Warren et al. 1967). In addition, immunomodulatory mechanisms have been described and appear to be dependent on cell-mediated immunity (Fanning et al. 1981).

Most of the host morbidity in schistosomiasis is the result of the parasite antigen-specific host immune responses that are expressed as inflammatory reactions. During the acute phase of the infection, parasite antigens evoke strong humoral and T-cell mediated immune responses, which decrease as the disease advances to chronic phase (Boros 1989), which is conspicuous for well-nourished hosts in experimental murine schistosomiasis. 


\section{Immune response in undernourished mice infected with $S$. mansoni}

Humoral immune response - According to Bastos et al. (1984), the most important immunoglobulins detected in the immune response of well-nourished schistosomeinfected mice are IgG1, IgA and IgM, also described in human patients. In Swiss Webster infected mice subjected to a low protein and multideficient diet, Coutinho et al. (1997) and Oliveira et al. (2004) studied the humoral immune response for some antibodies and found that the levels of serum soluble egg antigen (SEA)-specific IgG1, IgG2a, IgG2b and IgG3 were 2-4-fold lower than those found in well-nourished infected controls, probably indicating a generalised low protein nutritional status in these animals. Further experiments using inbred C57BL/6 infected mice led to similar results (Fig. 2) and in addition showed very low levels for $\operatorname{IgE}$ in these undernourished animals (Barros 2008). Undernutrition in these animals was induced by the Regional Basic Diet (Coutinho et al. 1997), which produces the clinical, biochemical and pathological features of marasmus in mice, one of the clinical forms of protein-energy malnutrition of humans (Teodósio et al. 1990, Coutinho et al. 1992).

Cellular immune response in undernourished infected mice - In the well-nourished host, the immune response in the course of schistosome infection progresses through at least three phases. In the first 3-5 weeks, during which the host is exposed to migrating immature parasites, the dominant response is Th1-like. As the parasites mature, mate and begin to produce eggs at weeks 5-6, the Th1 component decreases and this is associated with the emergence of a strong Th2 response, primarily induced by egg antigens. During the chronic phase of infection, the Th2 response is modulated and granulomas that form around newly deposited eggs are smaller than at earlier times during infection (Pearce \& MacDonald 2002). According to Cunningham-Rundles et al. (2005), in the human malnutrition (marasmus) the cellular immune system is more directly affected than the humoral immune system (McMurray et al. 1981, Chandra 1983) and in this situation lymphocyte subsets are altered (Nájera et al. 2004). Malnutrition is also an important cause of immuno-suppression (Peters-Golden et al. 2005). In children, adolescents and young adults infected with Schistosoma japonicum, hepatic fibrosis, the most important lesion found in chronic schistosomiasis, is associated with impaired nutritional status. It was hypothesised that the main mechanism through which hepatic fibrosis leads to undernutrition and anaemia is a systemic increase in the levels of pro-inflammatory cytokines, specifically IL-1 and IL- 6 and possibly TNF- $\alpha$ (Coutinho et al. 2005).

In the last few years, researchers in different countries have studied the role of nitric oxide (NO) in the immune response of mice infected with $S$. mansoni.

$\mathrm{NO}$, a biological molecular mediator produced in mammalian cells by the enzymatic oxidation of L-arginine mediated by NO synthase, is relevant as an intra and inter-cellular messenger and as a cytotoxin released during various physio-pathologic events, including im- munological reactions and inflammation. The inducible NO synthase (iNOS) is one of the three NOS isoforms present in virtually all cells and expressed in response to pro-inflammatory cytokines (IFN- $\gamma$, TNF- $\alpha$, IL-1 $\beta$ ) and/or microbial products (lipopolysaccharide). In wellnourished mice, NO production increases following the deposition of schistosome eggs in the liver. Overproduction of NO can induce tissue damage and may contribute to morbidity during schistosome infection (Brunet et al. 1999). However, NO appears to have anti-inflammatory or pro-inflammatory properties under different conditions (Kubes 1993). It has also been shown that inhibition of iNOS exacerbates the granulomatous reaction in vitro and this observation lead to the speculation of a probable regulatory role of $\mathrm{NO}$ in the development of chronic granulomatous inflammation (Oliveira et al. 1998, Hesse et al. 2001). Despite its potential for tissue

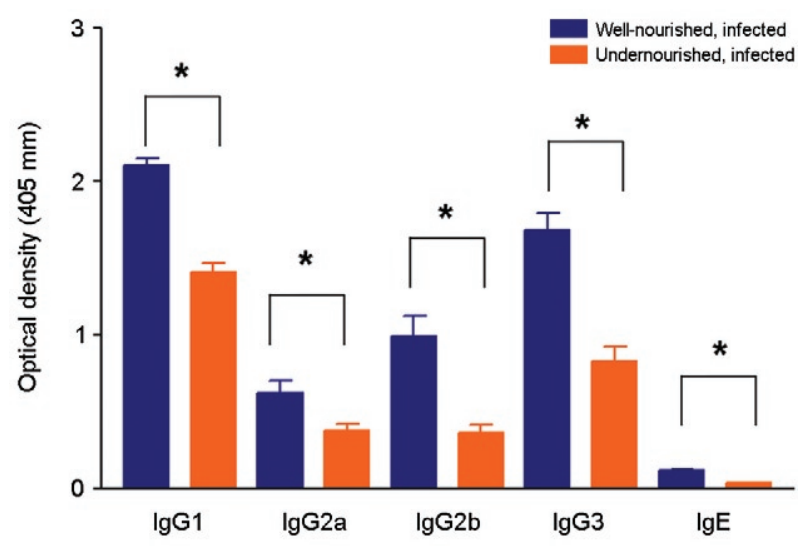

Fig. 2: serum antibody levels 150 days post-infection after soluble egg antigen stimulation (statistical significance $\mathrm{p}<0.05$ ). Asterisks mean statistical significance between infected well-nourished and undernourished mice.

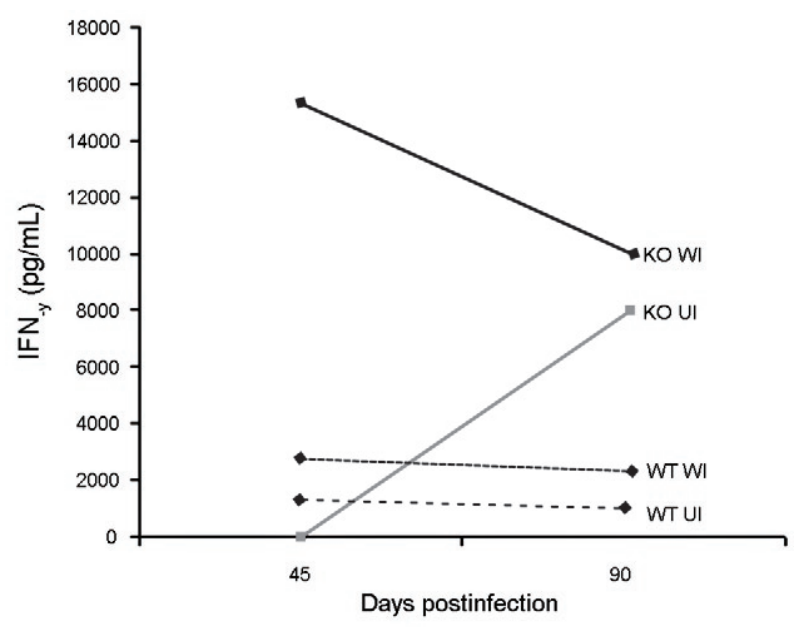

Fig. 3: kinetics of IFN- $\gamma$ in spleen cell culture of undernourished (KO UI) and well-nourished (KO WI) C57BL/6 knockout mice infected with Schistosoma mansoni. WT UI: undernourished, infected, wild type mice; WT WI: well-nourished, infected, wild type mice. 

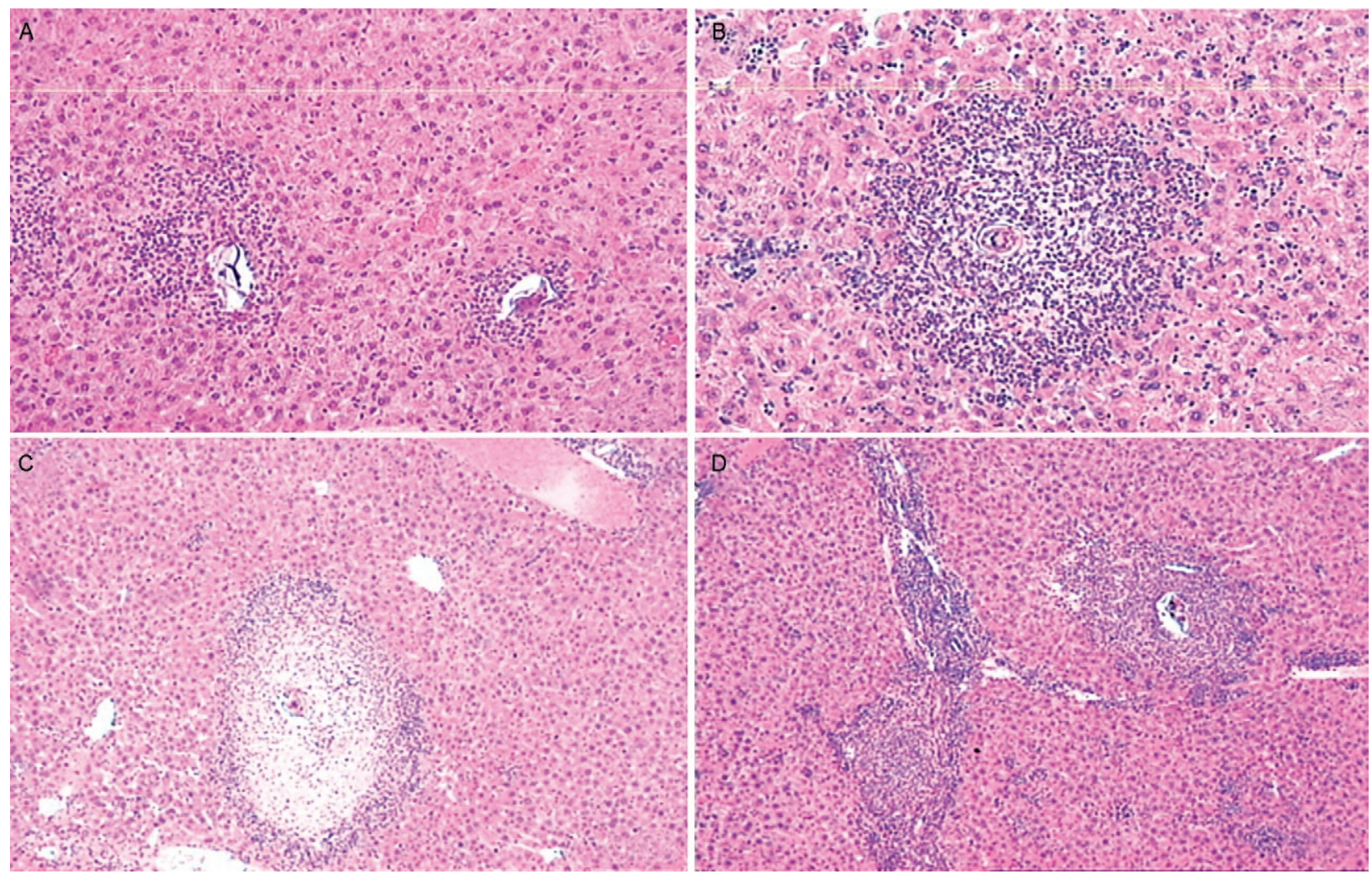

Fig. 4: histological appearance of the liver in undernourished and well-nourished C57BL/6 mice after 45 days of infection. A mild inflammatory acute exsudative reaction is seen around Schistosoma mansoni eggs in undernourished (A) and well-nourished (C) iNOS knockout mice, as compared to their wild-type controls (B and D, respectively). H\&E 200X (A, B), 100X (C, D).

damage by direct cytotoxic or cytostatic activity, $\mathrm{NO}$ appears to contribute to the maintenance of immunologic homeostasis through T-cell suppression or Th-cell differentiation (Bingisser et al. 1998).

Our laboratory is currently conducting studies on the kinetics of IFN- $\gamma$, IL-4 and IL-10 in undernourished infected iNOS knockout C57BL/6 inbred mice (Ramos 2007) at different time points (45 and 90 days post-infection). Cytokine assays are performed in culture supernatants of spleen cells after SEA stimulation by the capture ELISA technique. We have found that iNOS-2 knockout mice (KO mice) had diverging immunological profiles when compared to their wild-type controls. In knockout well-nourished infected mice the production of this proinflammatory cytokine decreased progressively from the 45th-90th day post-infection, while in knockout undernourished animals we noticed a progressive increase in the level of IFN- $\gamma$. Wild-type controls showed a lower secretion of this cytokine and its kinetics was similar and independent of the nutritional status of the rodents (Fig. 3).

In both undernourished and well-nourished C57BL/6 $\mathrm{KO}$, histological examination after 45 days of infection showed a mild acute inflammatory exudative reaction around trapped eggs in the liver, compared to the very dense acute inflammatory infiltrate (lymphocytes and polymorphonuclear cells) seen in wild-type controls (Fig. 4A-D). Comparison was being made between Figs
$\mathrm{A} \times \mathrm{B}$ and $\mathrm{C} \times \mathrm{D}$. Although a periovular granuloma can be seen in Fig. 4C (well-nourished iNOS KO), the exudative component is not as remarkable as in Fig. 4D (wildtype well-nourished mouse).

Knockout infected mice showed again diverging curves of IL-4 production as infection progressed (around 60 days), undernourished animals displaying ascending titres of IL-4 secretion. The same tendency was found in wild-type animals, but here the higher values were detected in well-nourished mice (Fig. 5).

IL-10 detection assays showed a similar kinetics trend, with diverging curves for $\mathrm{KO}$, but for well-nourished animals IL-10 secretion declined as infection matured, while deficient mice remained in an almost linear level of low production (Fig. 6).

Experiments on the kinetics of IL-13 have also been performed (Silva 2008) at different time points of the chronic phase in infected undernourished mice $(60,90$ and 150 days post-infection). These animals were not iNOS KO. We observed that after a transient peak, IL13 in undernourished infected mice fell abruptly to very low levels at 150 days post-infection, while well-nourished controls remained in the steady state as the chronic phase became well established (Fig. 7).

All of the results are shown as an arithmetic mean of three replicates (3 pools of 3 mice per group), with standard error of mean expressed as error bars. 


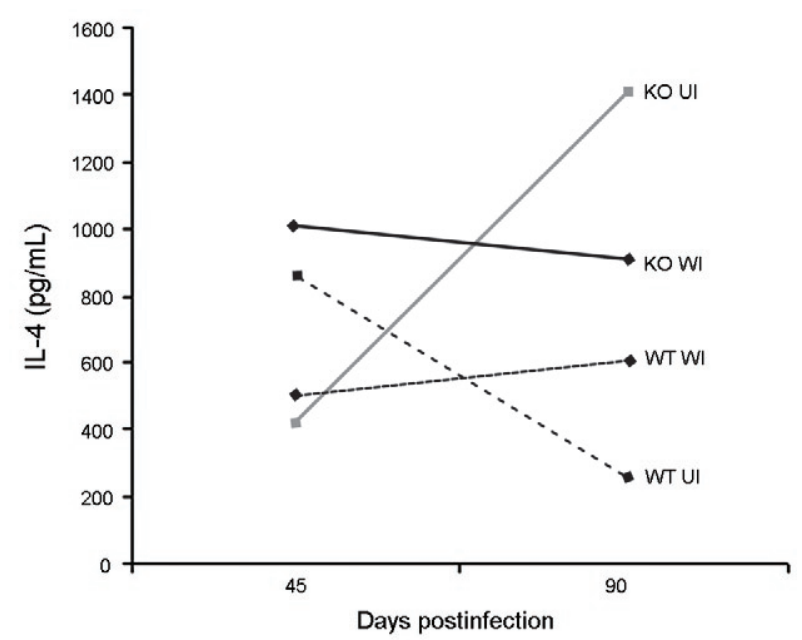

Fig. 5: kinetics of IL-4 in spleen cell culture of undernourished (KO $\mathrm{UI}$ ) and well-nourished (KO WI) C57BL/6 knockout mice infected with Schistosoma mansoni. WT UI: undernourished, infected, wild type mice; WT WI: well-nourished, infected, wild type mice.

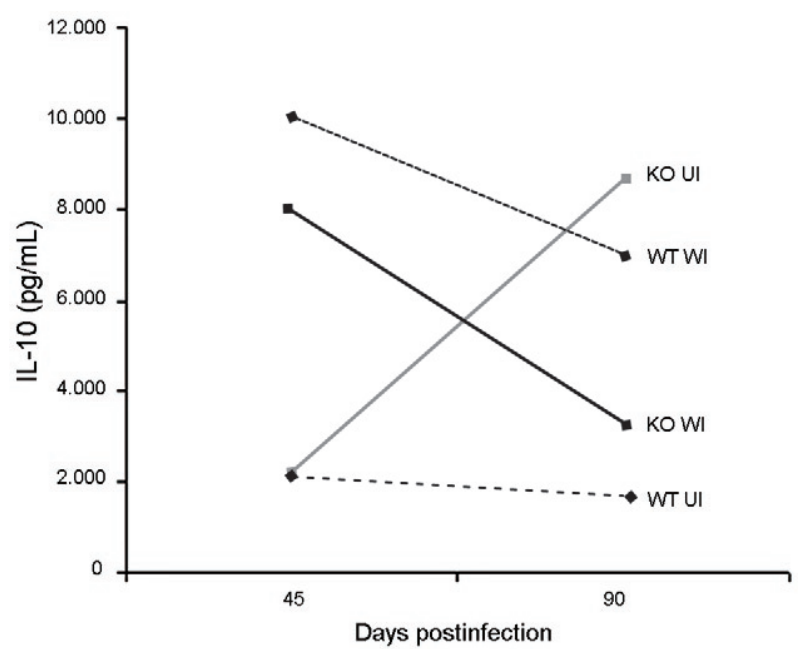

Fig. 6: kinetics of IL-10 in spleen cell culture of undernourished (KO $\mathrm{UI}$ ) and well-nourished (KO WI) C57BL/6 knockout mice infected with Schistosoma mansoni. WT UI: undernourished, infected, wild type mice; WT WI: well-nourished, infected, wild type mice.
Parasite infections cause malnutrition, impair the host immune response and are affected by host nutrition and immunity.

In schistosomiasis, the earliest hepatic granulomas are formed in the Th1 environment with down-regulation of Th1 and up-regulation of Th2 responses six weeks after infection (Todt et al. 2000).

Egg-induced granulomas formed during S. mansoni infection are $\mathrm{CD}^{+}$dependent cell-mediated hypersensitivity reactions associated with a strong $\mathrm{Th} 2$ response and are the principal pathologic manifestations of the disease in mice (Grzych et al. 1991, Lukacs \& Boros 1993).

Elevated IgE antibody response, although not specific, is a classic clinical sign of the infection by S. mansoni. Nevertheless, there is considerable controversy concerning the role of $\operatorname{IgE}$ in the host-parasite relationship based on the work in humans and other experimental models (Hagan 1993, Capron \& Capron 1994, Cutts \& Wilson 1997, Webster et al. 1997). Controversial findings have also been published concerning the biological role of $\operatorname{IgE}$ within the experimental model of the primary murine $S$. mansoni infection (Amiri et al. 1994). IgE is thought to represent a major defence component against schistosomiasis, presumably by targeting the effector cells against the invading larvae in antibody-dependent cell-mediated reactions. However, primary murine $S$. mansoni infection is not associated with detectable serum IgE until the worms mature, pair and deposit eggs (Sher et al. 1990).

In Brazil, adolescents with high resistance to infection by $S$. mansoni have specific IgE levels that are 6-8fold higher than those with low resistance. According to Capron \& Capron (1994), in a broader context, IgE response in schistosomiasis and its role in the protective immunity have to be regarded as part of the Th2-dependent regulatory circuit.

In malnourished children with parasitic infections, specific IgE response is reduced (Hagel et al. 2003). Ac-

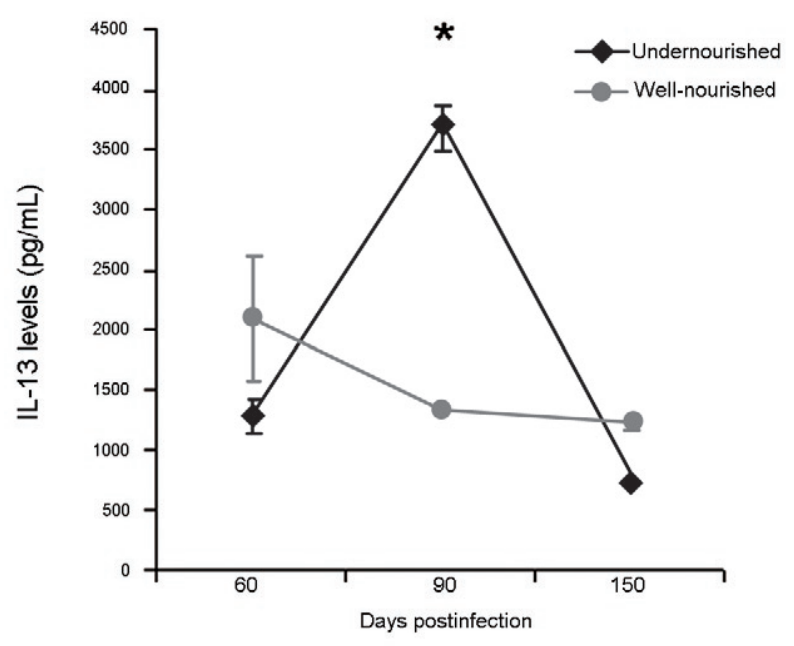

Fig. 7: kinetics of IL-13 in spleen cell culture of undernourished and wellnourished C57BL/6 mice infected with Schistosoma mansoni. Notice the variation in the production of this cytokine along the experiment.

cording to El Ridi et al. (2001), published data taken together indicate that IgE is neither essential nor detrimental to protection against $S$. mansoni in the primary infection.

In human schistosomiasis, the demonstration of $\operatorname{IgG}$ deposits in the abnormal Disse's space indicates the involvement of immunological reactions in this pathological alteration (Grimaud et al. 1977).

In chronic infections (20 weeks), Th2 responses are blunted (Chensue et al. 1992, Henderson et al. 1992). Borojevic (1992) regards the chronic phase of murine schistosomiasis as predominantly Th1 mediated, largely based on increasing ratio of IgG2a to IgG1 and decreasing eosino- 
phil and $\operatorname{IgE}$ levels in the chronically infected mice. IFN- $\gamma$, IL-4 and IL-10 exert cross-regulatory effects on the Th1Th2 balance as IL-4 drives the reaction toward Th2, IFN- $\gamma$ toward Th1 and IL-10 may inhibit either trend depending on the circumstances (Wynn et al. 1997, 1998, Boros \& Whitfield 1998).

IFN- $\gamma$ is a cytokine with important anti-fibrogenic properties (Fox et al. 1991). According to Rumbley et al. (1999), eosinophils form the majority of cytokine producing cells in the granuloma and are the dominant source of IL-4.

Anti IL-2 and anti IL-4 have shown to remarkably reduce the size of granulomas forming around injected eggs or antigen-coated beads (Lukacs \& Boros 1993, Wynn et al. 1993), but these antibodies have only moderate to minimal effects on the granulomatous inflammation around eggs laid in infected animals (Yamashita \& Boros 1992, Cheever et al. 1994).

IL-4 and IL-13 largely compensate each other during the formation of hepatic granulomas in infected mice. Thus, only minute granulomas are formed when both are suppressed.

Decreased levels of IL-10 have been associated with hepatic fibrosis in human S. mansoni infection (Booth et al. 2004) and are significantly higher in those with severe hepatic fibrosis (grades II and III) in the S. japonicum infected patients (Coutinho et al. 2005). This may reflect a counter-regulatory response to increased levels of pro-inflammatory cytokines. Although a previous study has shown that IL-10 plays a central regulatory role in the pathogenesis of schistosomiasis (Hoffman et al. 2000), its relationship to the nutritional status has not been studied (Coutinho et al. 2005).

Hepatic fibrosis in schistosome-infected mice is clearly linked to IL-13 and the Th2 response, although fibrosis sometimes occurs around the formed granulomas in the Th1 milieu (Hesse et al. 2000, Hoffmann et al. 2000). Although there is solid evidence in mice for the role of IL-13 and Type- 2 cytokines in the progression of hepatic fibrosis, the contribution of Type-1 and Type-2 associated cytokines to liver fibrosis in humans remains unclear (Abath et al. 2006).

These findings and our results on the association schistosomiasis/malnutrition collectively seem to indicate that (i) schistosome-infected undernourished mice are able to develop a humoral immune response, but antibody titres are much lower than in well-nourished controls, (ii) the cellular immune response is not suppressed in undernourished infected mice, but in acute infection IFN- $\gamma$ and IL-10 cytokines are secreted in smaller amounts than in well-nourished controls, (iii) in iNOS-2 KO, rising levels of IFN- $\gamma$, IL-4 and IL-10 cytokines can be detected in nutritionally deficient animals as the infection advances to the chronic phase, but the kinetics of their production seems to be opposite to that seen in well-nourished controls and (iv) the unexpected variation in IL-13 cytokine production observed in infected undernourished mice along different time points of schistosome infection may contribute to delay collagen synthesis in the liver of these animals. This event could explain the inability of deficient mice to develop the periportal liver fibrosis (pipe-stem like murine fi- brosis) described in both well-nourished outbred and inbred mice. However, further studies must be pursued to clarify the real meaning of these findings.

\section{ACKNOWLEDGEMENTS}

To Drs Silvia ML Montenegro and Claudia MA Costa, for their valuable participation in different steps of some experiments here reported, to Roni E de Araújo, for helping to prepare the histological sections and morphometry, to Claudia L Cavalcanti, who took care of the animals, and to Simone S de Souza, for secretarial assistance.

\section{REFERENCES}

Abath FG, Morais CN, Montenegro CE, Wynn TA, Montenegro SM 2006. Immunopathogenic mechanisms in schistosomiasis: what can be learnt from human studies? Trends Parasitol 22: 85-91.

Akpom CA, Warren KS 1975. Calorie and protein malnutrition in chronic murine schistosomiasis mansoni: effect on the parasite and the host. J Infect Dis 132: 6-14.

Amiri P, Haak-Frendscho M, Robbins K, McKerrow JH, Stewart T, Jardieu P 1994. Anti-immunoglobulin E treatment decreases worm burden and egg production in Schistosoma mansoni-infected normal and interferon $\gamma$ knockout mice. J Exp Med 180: 43-51.

Andrade ZA 1987. Patogenesis of pipe-stem fibrosis of the liver (experimental observation on murine schistosomiasis). Mem Inst Oswaldo Cruz 82: 325-334.

Andrade ZA, Cheever AW 1993. Characterization of the murine model of schistosomal hepatic periportal fibrosis ("pipestem" fibrosis). Int J Exp Pathol 74: 195-202.

Andrade ZA, Silva LM, Souza MM 1997. An experimental approach to the pathogenesis of "pipestem" fibrosis (Symmers' fibrosis of the liver). Mem Inst Oswaldo Cruz 92: 699-706.

Barros AF 2008. Resposta imune humoral e patologia hepática de camundongos desnutridos infectados com Schistosoma mansoni, MSc Thesis, Centro de Pesquisas Aggeu Magalhães-Fiocruz, Recife, 124 pp.

Bastos OC, Rangel HA, Magalhães LA, Piedrabuena AE 1984. Evolução das imunoglobulinas envolvidas na resposta imune de camundongos ao Schistosoma mansoni. Rev Saude Publica 18: 138-154.

Bhattacharyya KK 1965. Low protein diet as a factor in the production of experimental schistosomal hepatic fibrosis. J Pathol Bacteriol 89: 13-21.

Bingisser RM, Tilbrook PA, Holt PG, Kees UR 1998. Macrophagederived nitric oxide regulates $\mathrm{T}$ cell activation via reversible disruption of the Jak3/STAT5 signaling pathway. J Immunol 160: 5729-5734.

Booth M, Mwatha JK, Joseph S, Jones FM, Kadzo H, Ireri E, Kazibwe F, Kemijumbi J, Kariuki C, Kimani G, Ouma JH, Kabatereine NB, Vennervald BJ, Dunne DW 2004. Periportal fibrosis in human Schistosoma mansoni infection is associated with low IL-10, low IFN-gamma, high TNF-alpha or low RANTES, depending on age and gender. J Immunol 172: 1295-1303.

Borojevic R 1992. Experimental murine schistosomiasis mansoni: establishment of the chronic phase of the disease. Mem Inst Oswaldo Cruz 87 (Suppl. IV): 171-174.

Boros DL 1989. Immunopathology of Schistosoma mansoni infection. Clin Microbiol Rev 2: 250-269.

Boros DL, Whitfield JR 1998. Endogenous IL-10 regulates IFN- $\gamma$ and IL-5 cytokine production and the granulomatous response in schistosomiasis mansoni-infected mice. Immunology 94: 481-487. 
Brunet LR, Beall M, Dunne DW, PearceEJ 1999. Nitric oxide and the Th2 response combine to prevent severe hepatic damage during Schistosoma mansoni infection. J Immunol 163: 4976-4984.

Capron M, Capron A 1994. Immunoglobulin E and effector cells in schistosomiasis. Science 264: 1876-1877.

Chandra RK 1983. Numerical and functional deficiency in Thelper cells in protein energy malnutrition. Clin Exp Immunol 51: 126-132.

Chandra RK 1992. Protein energy malnutrition and immunological responses. J Nutr 122 (Suppl. 3): 597-600.

Cheever AW, Williams ME, Wynn TA, Finkelman FD, Seder RA, Cox TM, Hieny S, Caspar P, Sher A 1994. Anti-IL-4 treatment of Schistosoma mansoni-infected mice inhibits development of T cells and non-B, non-T cells expressing Th2 cytokines while decreasing egg-induced hepatic fibrosis. J Immunol 153: 753-759.

Chensue SW, Terebuh PD, Warmington KS, Hershey SD, Evanoff HL, Kunkel SL, Higashi GI 1992. Role of IL-4 and IFN-gamma in Schistosoma mansoni egg-induced hypersensitivity granuloma formation. Orchestration, relative contribution and relationship to macrophage function. J Immunol 148: 900-906.

Colley DG 1981. Immune responses and immunoregulation in experimental and clinical schistosomiasis. In JM Mansfield, ed., Parasitic diseases: the immunology, Marcel Dekker, New York, p. 1-83.

Coutinho EM 2004. Malnutrition and hepatic fibrosis in murine schistosomiasis. Mem Inst Oswaldo Cruz 99 (Suppl. I): 85-92.

Coutinho EM, Abath FG, de Freitas LP, Salzano AC, Lapa MA, Campos FS, Melo EB 1991. Liver and serum soluble protein changes and pathomorphology in undernourished mice with acute schistosomiasis mansoni. Rev Soc Bras Med Trop 24: 235-243.

Coutinho EM, Barros AF, Barbosa Jr A, Oliveira SA, Silva LM, Araújo RE, Andrade ZA 2003. Host nutritional status as a contributory factor to the remodeling of schistosomal hepatic fibrosis. Mem Inst Oswaldo Cruz 98: 919-925.

Coutinho EM, de Freitas LP, Abath FG 1992. The influence of the regional basic diet from Northeast Brazil on health and nutritional conditions of mice infected with Schistosoma mansoni. Rev Soc Bras Med Trop 25: 13-20.

Coutinho EM, de Souza MM, Silva LM, Cavalcanti CL, de Araújo RE, Barbosa Jr AA, Cheever AW, Andrade ZA 1997. Pathogenesis of schistosomal "pipestem" fibrosis: a low-protein diet inhibits the development of "pipestem" fibrosis in mice. Int J Exp Pathol 78: 337-342.

Coutinho EM, Silva FL, Barros AF, Araújo RE, Oliveira SA, Luna CF, Barbosa Jr AA, Andrade ZA 2007. Repeated infections with Schistosoma mansoni and liver fibrosis in undernourished mice. Acta Trop 101: 15-24.

Coutinho HM, McGarvey ST, Acosta LP, Manalo DL, Langdon GC, Leenstra T, Kanzaria HK, Solomon J, Wu H, Olveda RM, Kurtis JD, Friedman JF 2005. Nutritional status and serum cytokine profiles in children, adolescents and young adults with Schistosoma japonicum-associated hepatic fibrosis, in Leyte, Philippines. J Infect Dis 192: 528-536.

Cunningham-Rundles S, McNeeley DF, Moon A 2005. Mechanisms of nutrient modulation of the immune response. $J$ Allergy Clin Immunol 115: 1119-1128.

Cutts L, Wilson RA 1997. Elimination of a primary schistosome infection from rats coincides with elevated IgE titres and mast cell degranulation. Parasite Immunol 19: 91-102.

Dewitt WB 1957. Experimental schistosomiasis mansoni in mice maintained on nutritionally deficient diets. I. Effects of a Torula yeast ration deficient in factor 3, vitamin E and cystine. J Parasitol 43: 119-128.
El Ridi R, Ragab S, Lewis S, Afifi A 2001. Role of IgE in primary murine schistosomiasis mansoni. Scand J Immunol 53: 24-31.

Fanning MM, Peters PA, Davis RS, Kazura JW, Mahmoud AA 1981. Immunopathology of murine infection with Schistosoma mansoni: relationship of genetic background to hepatosplenic disease and modulation. J Infect Dis 144: 148-153.

Fox HS, Bond BL, Parslow TG 1991. Estrogen regulates the IFNgamma promoter. J Immunol 146: 4362-4367.

Fraker PJ, King LE, Laakko T, Vollmer TL 2000. The dynamic link between the integrity of the immune system and zinc status. J Nutr 130 (Suppl. 5): 1399S-1406S.

Grimaud JA, Borojevic R, Bradrawy NE 1977. IgG deposits and Disse's space pathology in human schistosomal liver. Experientia 33: 1078-1079.

Grzych JM, Pearce E, Cheever A, Caulada ZA, Caspar P, Heiny S, Lewis F, Sher A 1991. Egg deposition is the major stimulus for the production of $\mathrm{Th} 2$ cytokines in murine schistosomiasis mansoni. J Immunol 146: 1322-1327.

Hagan P 1993. IgE and protective immunity to helminth infections. Parasite Immunol 15: 1-4.

Hagel I, Lynch NR, Puccio F, Rodriguez O, Luzondo R, Rodríguez P, Sánchez P, Cabrera CM, Di Prisco MC 2003. Defective regulation of the protective IgE response against intestinal helminth Ascaris lumbricoides in malnourished children. $J$ Trop Pediatr 49: 136-142.

Hashem M, Fahmy SA 1962. The effects of dietetic deficiency on the evolution of bilharzial hepatic fibrosis in the experimental animals. In Proceedings of the International Symposium on Bilharziasis, Cairo, p. 115-121.

Henderson GS, Lu X, McCurley TL, Colley DG 1992. In vivo molecular analysis of lymphokines involved in the murine immune response during Schistosoma mansoni infection. II. Quantification of IL-4 mRNA, IFN- $\gamma$ mRNA and IL-2 mRNA levels in the granulomatous livers, mesenteric lymph nodes and spleens during the course of modulation. J Immunol 148: 2261-2269.

Hesse M, Cheever AW, Jankovic D, Wynn TA 2000. NOS-2 mediates the protective anti-inflammatory and antifibrotic effects of the Th1-inducing adjuvant, IL-12, in a Th2 model of granulomatous disease. Am J Pathol 157: 945-955.

Hesse M, Modolell M, La Flamme AC, Schito M, Fuentes JM, Cheever AW, Pearce EJ, Wynn TA 2001. Differential regulation of nitric oxide synthase- 2 and arginase-1 by type1/type 2 cytokines in vivo: granulomatous pathology is shaped by the pattern of L-arginine metabolism. J Immunol 167: 6533-6544.

Hoffman KF, Cheever AW, Wynn TA 2000. IL-10 and the dangers of immune polarization: excessive type 1 and type 2 cytokine responses induce distinct forms of lethal immunopathology in murine schistosomiasis. J Immunol 164: 6406-6416.

Jankovic D, Cheever AW, Kullberg MC, Wynn TA, Yap G, Caspar P, Lewis FA, Clynes R, Ravetch JV, Sher A 1998. CD4+ T cellmediated granulomatous pathology in schistosomiasis is downregulated by a $\mathrm{B}$ cell-dependent mechanism requiring $\mathrm{Fc}$ receptor signaling. J Exp Med 187: 619-629.

Kanuft RF, Warren KS 1969. The effect of calorie and protein malnutrition on both the parasite and the host in acute murine schistosomiasis mansoni. J Infect Dis 120: 560-575.

Kubes P 1993. Polymorphonuclear leukocyte-endothelium interactions: a role for pro-inflammatory and anti-inflammatory molecules. Can J Physiol Pharmacol 71: 88-97. 
Landgraf MA, Tostes R de C, Borelli P, Zorn TM, Nigro D, Carvalho MH, Fortes ZB 2007. Mechanisms involved in the reduced leukocyte migration in intrauterine undernourishment. Nutrition 23: 145-156.

Lukacs NW, Boros DL 1993. Lymphokine regulation of granuloma formation in murine schistosomiasis mansoni. Clin Immunol Immunophatol 68: 57-63.

Mansour MM, Mikhail MM, Guirgis NI 1983. Effect of zinc supplementation on S. mansoni-infected hamsters. Ann Trop Med Parasitol 77: 517-521.

Mason JB, Musgrove P, Habicht JP 2003. At least one-third of poor countries' disease burden is due to malnutrition. Working Paper 1. Disease Control Priorities Project, Fogarty International Center/National Institutes of Health, Maryland, $49 \mathrm{pp}$.

Mathew RC, Boros DL 1986. Anti-L3T4 antibody treatment suppresses hepatic granuloma formation and abrogates antigen-induced interleukine-2 production in Schistosoma mansoni infection. Infect Immun 54: 820-826.

McMurray DN, Loomis SA, Casazza LJ, Rey H, Miranda R 1981. Development of impaired cell-mediated immunity in mild and moderate malnutrition. Am J Clin Nutr 34: 68-77.

Meira DA 1995. Interactions of infection, nutrition and immunity. Rev Soc Bras Med Trop 28: 315-319.

Nájera O, González C, Toledo G, López L, Ortiz R 2004. Flow cytometry study of lymphocyte subsets in malnourished and wellnourished children with bacterial infections. Clin Diagn Lab Immunol 11: 577-580.

Oliveira DM, Silva-Teixeira DN, Carmo SA, Goes AM 1998. Role of nitric oxide on human schistosomiasis mansoni: upregulation of in vitro granuloma formation by $\mathrm{N}$ omega-nitro-L-arginine methyl ester. Nitric Oxide 2: 57-65.

Oliveira SA, Silva LM, Barbosa Júnior AA, Ribeiro-Dos-Santos R, Coutinho EM, Andrade ZA, Soares MB 2004. Decreased humoral and pathologic responses in undernourished mice infected with Schistosoma mansoni. Parasitol Res 93: 30-35.

Parent G, Rousseaux-Prevost R, Carlier Y, Capron A 1984. Influence of vitamin A on the immune response of Schistosoma mansoniinfected rats. Trans R Soc Trop Med Hyg 78: 380-383.

Pearce EJ, MacDonald AS 2002. The immunobiology of schistosomiasis. Nat Rev Immunol 2: 499-511.

Peters-Golden M, Canetti C, Mancuso P, Coffey MJ 2005. Leukotrienes: underappreciated mediators of innate immune responses. J Immunol 174: 589-594.

Ramos RP 2007. Infecção esquistossomótica aguda: produção de citocinas em camundongos desnutridos e deficientes em iNOS, MSc Thesis, Centro de Pesquisas Aggeu Magalhães-Fiocruz, Recife, 73 pp.

Rumbley CA, Sugaya H, Zekavat SA, El Refaei M, Perrin PJ, Phillips SM 1999. Activated eosinophils are the major source of Th2associated cytokines in the schistosome granuloma. J Immunol 162: 1003-1009.

Scrimshaw NS, SanGiovanni JP 1997. Synergism of nutrition, infection and immunity: an overview. Am J Clin Nutr 66 (Suppl.): 464S-477S.
Sher A, Coffman RL, Hieny S, Cheever AW 1990. Ablation of eosinophil and IgE responses with anti-IL-5 or anti-IL-4 antibodies fails to affect immunity against Schistosoma mansoni in the mouse. J Immunol 145: 3911-3916.

Silva FL 2008. Resposta imune celular e patologia hepática de camundongos desnutridos, infectados com Schistosoma mansoni, MSc Thesis, Centro de Pesquisas Aggeu Magalhães-Fiocruz, Recife, $112 \mathrm{pp}$.

Smithers SR, Doenhoff MJ 1982. Schistosomiasis. In S Cohen, KS Warren (eds.), Immunology of parasitic diseases, Blackwell, Oxford, p. 527.

Solomons NW 2007. Malnutrition and infection: an update. Br J Nutr 98 (Suppl. 1): S5-S10.

Teodósio NR, Lago ES, Romani SA, Guedes RC 1990. A regional basic diet from Northeast Brazil as a dietary model of experimental malnutrition. Arch Latinoam Nutr 40: 533-547.

Todt JC, Whitfield JR, Ivard SR, Boros DL 2000. Down-regulation of interleukin-12, interleukin-12R expression/activity mediates the switch from Th1 to Th2 granuloma response during murine schistosomiasis mansoni. Scand J Immunol 52: 385-392.

Warren KS 1968. Pathophysiology and pathogenesis of hepatosplenic schistosomiasis mansoni. Bull N Y Acad Med 44: 280-294.

Warren KS 1982. The secret of the immunopathogenesis of schistosomiasis: in vivo models. Immunol Rev 61: 189-213.

Warren KS, Domingo EO, Cowan RB 1967. Granuloma formation around schistosome eggs as a manifestation of delayed hypersensitivity. Am J Pathol 51: 735-756.

Webster M, Correa-Oliveira R, Gazzinelli G, Viana IR, Fraga LA, Silveira AM, Dunne DW 1997. Factors affecting high and low human IgE responses to schistosome worm antigens in an area of Brazil endemic for Schistosoma mansoni and hookworm. Am J Trop Med Hyg 57: 487-494.

WFP - World Food Programme 2006. [homepage on the internet]. Roma: United Nations World Food Program; [updated 2007 May 18; cited 2008 Aug 9]. World Hunger Map; [about 1 screen]. Available from: http://www.geographictravels.com/2008/07/ world-hunger-map.html.

Wynn TA, Cheever AW, Williams ME, Hieny S, Caspar P, Kühn R, Müller W, Sher A 1998. IL-10 regulates liver pathology in acute murine schistosomiasis mansoni but is not required for immune down-modulation of chronic disease. J Immunol 160: 4473-4480.

Wynn TA, Eltoum I, Cheever AW, Lewis FA, Gause WC, Sher A 1993. Analysis of cytokine mRNA expression during primary granuloma formation induced by eggs of Schistosoma mansoni. J Immunol 151: 1430-1440.

Wynn TA, Morawetz R, Scharton-Kersten T, Hieny S, Morse HC 3rd, Kühn R, Müller W, Cheever AW, Sher A 1997. Analysis of granuloma formation in double cytokine-deficient mice reveals a central role for IL-10 in polarizing both T helper cell 1 and T helper cell 2-type cytokine responses in vivo. J Immunol 159: 5014-5023.

Yamashita T, Boros DL 1992. IL-4 influences IL-2 production and granulomatous inflammation in murine schistosomiasis mansoni. J Immunol 149: 3659-3664. 